\title{
A new slurry infiltration method to enhance the wear resistance of bulk graphite with development of reinforced graphitic composites including SiC or Si3N4 hard particles DOI:
}

10.1016/j.jeurceramsoc.2019.01.053

\section{Document Version \\ Accepted author manuscript}

Link to publication record in Manchester Research Explorer

Citation for published version (APA):

Hernandez, M. A., Bakoglidis, K. D., \& Xiao, P. (2019). A new slurry infiltration method to enhance the wear resistance of bulk graphite with development of reinforced graphitic composites including $\mathrm{SiC}$ or $\mathrm{Si}_{3} \mathrm{~N}_{\text {, hard }}$ particles. Journal of the European Ceramic Society. https://doi.org/10.1016/j.jeurceramsoc.2019.0 3.053

\section{Published in:}

Journal of the European Ceramic Society

\section{Citing this paper}

Please note that where the full-text provided on Manchester Research Explorer is the Author Accepted Manuscript or Proof version this may differ from the final Published version. If citing, it is advised that you check and use the publisher's definitive version.

\section{General rights}

Copyright and moral rights for the publications made accessible in the Research Explorer are retained by the authors and/or other copyright owners and it is a condition of accessing publications that users recognise and abide by the legal requirements associated with these rights.

\section{Takedown policy}

If you believe that this document breaches copyright please refer to the University of Manchester's Takedown Procedures [http://man.ac.uk/04Y6Bo] or contact uml.scholarlycommunications@manchester.ac.uk providing relevant details, so we can investigate your claim.

\section{OPEN ACCESS}




\section{Accepted Manuscript}

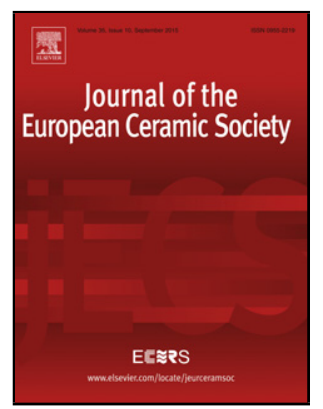

Title: A new slurry infiltration method to enhance the wear resistance of bulk graphite with development of reinforced graphitic composites including $\mathrm{SiC}$ or $\mathrm{Si}_{3} \mathrm{~N}_{4}$ hard particles

Authors: Miguel A. Hernandez, Konstantinos D. Bakoglidis, Ping Xiao

PII: S0955-2219(19)30079-2

DOI: https://doi.org/10.1016/j.jeurceramsoc.2019.01.053

Reference: JECS 12320

To appear in: Journal of the European Ceramic Society

Received date: $\quad 3$ October 2018

Revised date: $\quad 30$ January 2019

Accepted date: $\quad 30$ January 2019

Please cite this article as: Hernandez MA, Bakoglidis KD, Xiao P, A new slurry infiltration method to enhance the wear resistance of bulk graphite with development of reinforced graphitic composites including $\mathrm{SiC}$ or $\mathrm{Si}_{3} \mathrm{~N}_{4}$ hard particles, Journal of the European Ceramic Society (2019), https://doi.org/10.1016/j.jeurceramsoc.2019.01.053

This is a PDF file of an unedited manuscript that has been accepted for publication. As a service to our customers we are providing this early version of the manuscript. The manuscript will undergo copyediting, typesetting, and review of the resulting proof before it is published in its final form. Please note that during the production process errors may be discovered which could affect the content, and all legal disclaimers that apply to the journal pertain. 


\title{
A new slurry infiltration method to enhance the wear resistance of bulk graphite with development of reinforced graphitic composites including $\mathrm{SiC}_{\text {or }} \mathrm{Si}_{3} \mathrm{~N}_{4}$ hard particles
}

\author{
Miguel A. Hernandez ${ }^{*}, 1$, Konstantinos D. Bakoglidis ${ }^{1}$, Ping Xiao ${ }^{1}$ \\ ${ }^{1}$ School of Materials, University of Manchester, Manchester M13 9PL, United Kingdom \\ *Corresponding author. Tel: +44 7393 833431. Email: miguel.hernandez@ postgrad.manchester.ac.uk \\ (Miguel A. Hernandez)
}

\begin{abstract}
Bulk graphite blocks are infiltrated by a Si slurry method to form composites of graphite containing $\mathrm{SiC}$ or $\mathrm{Si}_{3} \mathrm{~N}_{4}$ reinforcements, in order to enhance the wear resistance of the graphitic structure. The microstructure of the $\mathrm{SiC}$ reinforcements includes nuclei grains and whiskers, while the microstructure of the $\mathrm{Si}_{3} \mathrm{~N}_{4}$ reinforcements is a mixture of fine grains, grains of blade- and needle-like morphology. The wear rate of the $\mathrm{SiC}$ - and $\mathrm{Si}_{3} \mathrm{~N}_{4}$-reinforced graphitic block is 77.7 and $42.8 \mu \mathrm{m}^{3} / \mathrm{Nmm}$, respectively, as measured using an unlubricated pin-on-disc test. These values are $\sim 55 \%$ and $75 \%$ lower than the wear rate of the reference graphite $\left(174 \mu \mathrm{m}^{3} / \mathrm{Nmm}\right)$. The coefficient of friction of the composites is as low as the coefficient of friction of the reinforcement-free graphite, showing values of $\sim 0.17$.
\end{abstract}

\section{Keywords}

Infiltration; Composite graphite; $\mathrm{SiC}$ reinforcement; $\mathrm{Si}_{3} \mathrm{~N}_{4}$ reinforcement; Wear

\section{Introduction}

Molded graphite stands out for its high thermal and electrical conductivity (159 $\mathrm{W} / \mathrm{mK}$ and $7.6 \mu \Omega \mathrm{m}$ at room temperature, respectively), refractory properties, thermal-shock resistance, chemical resistance, and good lubricious properties [1]. Graphite is used as a solid lubricant in many industrial applications, such as sealing rings, bearings, piston rings, as well as pump and valve parts [2]. However, graphite poses low hardness and as a result shows high wear under excessive tribological contacting [3], [4]. Thus the above tribological applications demand the improvement of the wear resistance of graphite without compromising its lubrication capabilities. This will lead to significant increase of the lifetime of the graphitic components used in tribological applications and reduced maintenance costs.

The increase of the wear resistance and hardness of bulk materials can be achieved by embedding harder particles (reinforcements) in the bulk than the material of the matrix [5], [6]. Hard $\mathrm{SiC}$ and $\mathrm{Si}_{3} \mathrm{~N}_{4}$ reinforcement ( 23 and $14 \mathrm{GPa}$, respectively [7], [8]) have already been used with success in carbon fibers, increasing their hardness and toughness [9], [10]. Similar effects are observed in other $\mathrm{SiC}$ and $\mathrm{Si}_{3} \mathrm{~N}_{4}$ particle - reinforced composites with matrices of molde graphite, of bulk aluminum, copper and polymers [11], [12], [13], [14], [15], [16]. More specifically, reinforcing of molded polycrystalline graphite has been 
reported using reactive melt $\mathrm{Si}$ infiltration with intention to improve the wear resistance of the graphitic matrix [11].

Reactive infiltration methods allow for fast and low-cost synthesis of ceramic materials, such as polymer infiltration and pyrolysis (PIP) [17], chemical vapor infiltration (CVI) [18], reactive melt infiltration (RMI) [19], reaction bonded (RB) [20], slurry infiltration [21], sol-gel infiltration [22], or combination of these [23]. The demands of metallurgical industry for mass production direct the fabrication of ceramic materials as refractories to more versatile and cost effective methods. Slurry infiltration is a simpler and more economical technique [24]. In comparison with the reactive melt $\mathrm{Si}$ infiltration, $\mathrm{Si}$ slurry infiltration requires lower temperature, is lower cost and the reinforcements formed do not contain unreactive Si [11]. In this method, powders of ceramics are dispersed in a solution, which is infiltrated into a porous block, which constitutes the matrix. Then, the infiltrated block is heated to generate the reaction between the ceramic powders and the matrix [25]. In the past, this technique has been used in order to introduce $\mathrm{SiC}$ and $\mathrm{Si}_{3} \mathrm{~N}_{4}$ particles in carbon fibers [26].

The formation of $\mathrm{SiC}$ using graphite as source of $\mathrm{C}$ is favored by the high density of defects present in graphite [27]. $\mathrm{Si}, \mathrm{SiO}$ and $\mathrm{CO}$ vapors are produced when $\mathrm{Si}$ and graphite powders are mixed and heated in coke bed at $1200-1400{ }^{\circ} \mathrm{C}$, even at very low $\mathrm{O}$ concentrations in the gas flow of $0.001 \%$ and form beta-SiC $(\beta-\mathrm{SiC})$ nuclei and whiskers [28], [27]. [27]. $\mathrm{Si}_{3} \mathrm{~N}_{4}$ can be formed by the direct reaction of $\mathrm{Si}$ with a $\mathrm{N}_{2}$ gas at $1400{ }^{\circ} \mathrm{C}$, in a process which is known as nitridation [28]. In this case, alpha- $\mathrm{Si}_{3} \mathrm{~N}_{4}\left(\alpha-\mathrm{Si}_{3} \mathrm{~N}_{4}\right)$ is formed by the reaction of molecular $\mathrm{N}_{2}$ and gaseous $\mathrm{Si}$ and beta- $\mathrm{Si}_{3} \mathrm{~N}_{4}\left(\beta-\mathrm{Si}_{3} \mathrm{~N}_{4}\right)$ is produced by the reaction between atomic $\mathrm{N}$ and solid or liquid $\mathrm{Si}$ [28]. A dependency of the $\mathrm{Si}_{3} \mathrm{~N}_{4}$ morphology with temperature, time of reaction, and gas flow rate is concluded [29].

Hard $\mathrm{SiC}$ and $\mathrm{Si}_{3} \mathrm{~N}_{4}$ particles can be used to reinforce soft graphite (52.2 $\mathrm{MPa}$ [3]), forming reinforced ceramic composites. In this study, we propose for the first time, the fabrication of graphitic composites consisted of $\mathrm{SiC}$ or $\mathrm{Si}_{3} \mathrm{~N}_{4}$ reinforcements by reactive infiltration. We describe the infiltration method as well as the kinetics and thermodynamics of the synthesis of reinforced graphitic matrices with $\mathrm{SiC}$ or $\mathrm{Si}_{3} \mathrm{~N}_{4}$ particles. Moreover, we evaluate the wear resistance of reinforced graphite using an unlubricated pin-on-disk test, extracting as lower friction coefficient as in the graphite and wear rates which are $\sim 55 \%$ and $75 \%$ lower than the wear rate of reinforcement-free graphite.

\section{Materials and methods}

Orthorhombic graphite specimens from a cathode block with dimensions of $12 \mathrm{~mm} \mathrm{x}$ $12 \mathrm{~mm}$ x $3 \mathrm{~mm}$ (Bawtry Carbon International Ltd.) were grinded sequentially, using SiC papers with a grit size of 400, 800, 1200, and 2400 and polished using a diamond paste with a diameter of $1 \mu \mathrm{m}$. The polished samples were ultrasonically cleaned in ethanol for 10 minutes and dried at a temperature of $60{ }^{\circ} \mathrm{C}$, using a hot plate in air. Figure 1 shows a flowchart of the procedure followed to synthesize composites of graphite containing $\mathrm{SiC}$ particles $(\mathrm{g} / \mathrm{SiC})$ and 
composites of graphite containing $\mathrm{Si}_{3} \mathrm{~N}_{4}$ particles $\left(\mathrm{g} / \mathrm{Si}_{3} \mathrm{~N}_{4}\right)$. Si slurries were prepared using a mixture of Si powders (325 mesh, $99 \%$ trace metals basis, Sigma-Aldrich) in ethanol and a powder-to-ethanol ratio of 2:1. The mixture was stirred for $5 \mathrm{~h}$. Then, $1.33 \mathrm{wt} . \%$ of dispersant (polyethyleneimine, Sigma-Aldrich) and 1.33 wt.\% of binder (Butvar B-98, Sigma-Aldrich) were added in the Si slurry and was stirred for two days. After stirring, the graphite substrates were immersed in the slurry and placed in a vacuum chamber (Cast N' Vac 1000, Buehler, USA), applying a low vacuum with a pressure of $85 \mathrm{kPa}$ for 5 minutes. Then, the graphite substrates were removed from the slurry, placed again inside the vacuum chamber, and dried, applying a pressure of $85 \mathrm{kPa}$ for 3 hours. The dry samples were heated at a temperature of $1400{ }^{\circ} \mathrm{C}$ for 2 hours in Ar atmosphere to form g/SiC and in $\mathrm{N}_{2}$ atmosphere forming $\mathrm{g} / \mathrm{Si}_{3} \mathrm{~N}_{4}$, using a cyclic process with a heating-cooling rate of $400{ }^{\circ} \mathrm{C} /$ hour. After heating, the samples were grinded using SiC papers with a grit size of 400, 800, 1200, and 2400 and polished with diamond paste with a diameter of $1 \mu \mathrm{m}$ in order to reveal their composite microstructure. The resulted specimens were cleaned ultrasonically in an ethanol bath for 10 minutes and dried at $60{ }^{\circ} \mathrm{C}$ in air, using a hot plate.

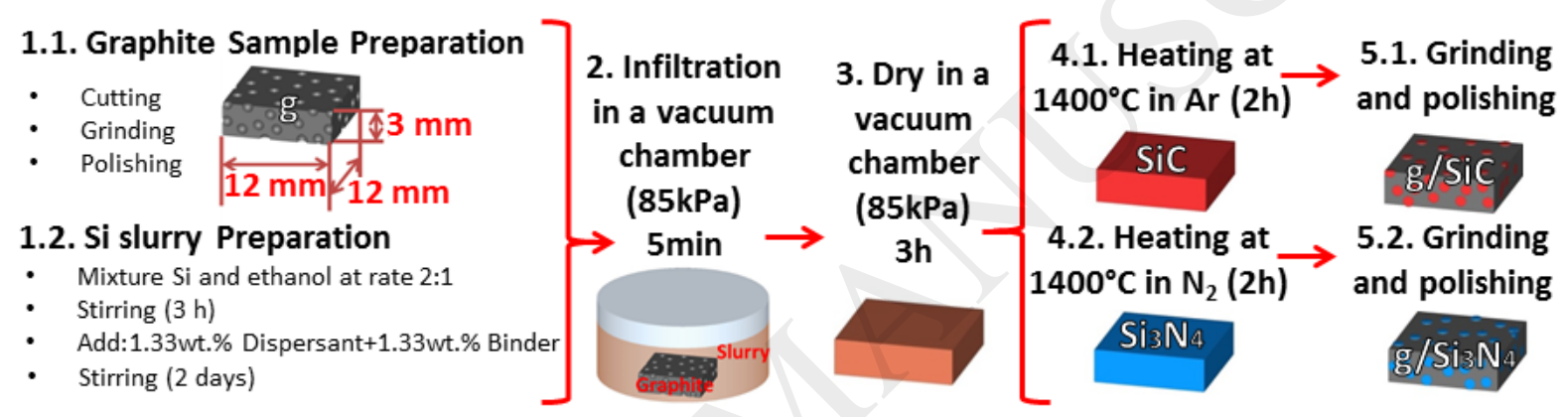

Figure 1: A flowchart showing the method followed for the synthesis of the graphitic composites. The graphite blocks were cut in a volume of $12 \mathrm{~mm}$ x $12 \mathrm{~mm}$ x $3 \mathrm{~mm}$ and subsequently were grinded and polished (1.1). A Si slurry was formed using Si powder, ethanol, a binder, and a dispersant (1.2.). The graphite blocks were infiltrated for 5 minutes. (2) and dried for 3 hours in vacuum (3). Then, the infiltrated blocks were heated at $1400{ }^{\circ} \mathrm{C}$ for 2 hours in $\mathrm{Ar}$ or $\mathrm{N}_{2}$ to form a graphitic composite containing $\mathrm{SiC}$ or $\mathrm{Si}_{3} \mathrm{~N}_{4}$ reinforcements, respectively (4). After heating, the samples were grinded and polished in order to reveal their microstructure (5).

The open porosity and bulk density of the graphite as well as the composite samples were measured by immersion according to the ASTM C20 test procedure [30]. The phases of the materials were identified by x-ray diffraction (XRD) using a PANaytical X'Pert Pro comprising a $\mathrm{Cu}-\mathrm{K}_{\mathrm{a}} \mathrm{X}$-ray source at an energy of $40 \mathrm{keV}$ and a current of $40 \mathrm{~mA}$. The measurements were performed in a range of different tilting angles from 10 to $80^{\circ}$. A semiquantitative analysis for the determination of the phases was carried out using the X'Pert HighScore software from PANalytical. The microstructure of the materials as well as the morphology of the wear tracks were observed using scanning electron microscopy (SEM, Q250) in secondary electron (SE) mode and the composition of the composites was determined by energy dispersive $\mathrm{x}$-ray spectroscopy (EDX), using an acceleration voltage of $20 \mathrm{kV}$, respectively. The images were studied using a qualitative digital analysis (QDIA), in ImageJ, 
in order to estimate the total porosity of the reference graphite block and the composites formed after infiltration, the width of the worn surface, and the formed debris. The stability diagram of the $\mathrm{Si}-\mathrm{C}-\mathrm{N}-\mathrm{O}$ system was constructed as a function of nitrogen and oxygen pressure following the steps described in the literature [31]. The Gibbs free energy, $\Delta G$, of the possible reactions were calculated using the software Thermo-calc ("Thermo-calc software") at a temperature of $1400{ }^{\circ} \mathrm{C}$ and a pressure of $1 \mathrm{~atm}$.

In order to measure the hardness $\left(\mathrm{H}_{\mathrm{v}}\right)$ of the samples, we used a Vickers hardness tester-Armstrong Pedestal, utilizing a square-based pyramid diamond indenter with an included angle of $136^{\circ}$. A normal load of $10 \mathrm{~kg}$ was applied with an increasing rate of 3.4 $\mathrm{kg} / \mathrm{s}$ and duration of $12 \mathrm{~s}$ at the surface of the samples. The values of the Vickers hardness, $\mathrm{H}_{\mathrm{V}}$, in $\mathrm{MPa}$, were calculated, using the diagonal lengths of the indentation measured with an optical microscope [32].

The surface roughness, $S_{a}$, of the samples was measured on an area of $500 \times 500 \mu \mathrm{m}^{2}$ using a laser scanning confocal microscope (Keyence VK-X200 series) and the data were treated using the software MultiFile Analyzer. For the calculation of the roughness of the composites, areas which included 50\% graphite and 50\% reinforcements on the surface were used.

A pin-on-disk rig (Pod-2, Teer Coatings Ltd) was used to measure the coefficient of friction $(\mathrm{CoF})$ and the wear rate $\left(\mathrm{K}_{\mathrm{D}}\right)$ of the materials. Different steel balls (graded 51200) with a diameter of $5 \mathrm{~mm}$ and a hardness of $7846 \mathrm{MPa}(800 \mathrm{HV}$ [33]) were used as pins for each wear test. The tangential force and the $\mathrm{CoF}$ were continuously recorded through a computer. The experiments were carried out using a normal load of $10 \mathrm{~N}$, corresponding to a maximum contact pressure of $198.4 \mathrm{MPa}$, and a constant sliding speed of $4 \mathrm{~cm} / \mathrm{s}$, corresponding to a rotation speed of $400 \mathrm{rpm}$. The duration of the tests was $3600 \mathrm{~s}$. The experiments were carried out at a temperature of $22{ }^{\circ} \mathrm{C}$ and a relative humidity of $50 \%$, without the use of liquid lubrication.

The width, a, of the worn surfaces was measured using an optical microscope. The depth of penetration, $h$, was calculated geometrically using eq. (1):

$$
h=R-\sqrt{R^{2}-(a / 2)^{2}},
$$

where $\mathrm{R}$ is the radius of the pin. The volume of the removed material, $\mathrm{V}$, from the track was calculated geometrically using eq. (2):

$$
V=2 \pi R_{\text {Track }} \cdot\left(1-\frac{P}{100}\right) \cdot\left[R^{2} \arccos \left(\frac{R-h}{R}\right)-(R-h)^{2} \operatorname{tg}\left(\arccos \left(\frac{R-h}{R}\right)\right)\right]
$$

where $R_{\text {Track }}$ is the radius of the wear track and $P$ the porosity (\%). Thus, an estimation of the wear rates $\left(\mathrm{K}_{\mathrm{D}}\right)$ of the composites and the reference graphite sample were given by eq. (3),

$$
K_{D}=\frac{V}{F \cdot S}
$$


where $F$ is the normal applied load and $s$ the sliding distance. After each test, the balls were ultrasonically cleaned with ethanol and weighed using an analytical balance.

\section{Results}

\subsection{Structural and mechanical properties of the samples}

The phase stability diagram of the system $\mathrm{Si}-\mathrm{C}-\mathrm{O}-\mathrm{N}$ at $1400{ }^{\circ} \mathrm{C}$ as a function of $\mathrm{O}_{2}$ and $\mathrm{N}_{2}$ partial pressures $\left(\mathrm{P}_{\mathrm{O} 2}\right.$ and $\left.\mathrm{P}_{\mathrm{N} 2}\right)$ is represented in Fig. 2. According to the stability phase diagram, under $\mathrm{P}_{\mathrm{O} 2}$ lower than $10^{-2.013} \mathrm{~atm}$, the phase of $\mathrm{SiC}_{\text {or }} \mathrm{Si}_{3} \mathrm{~N}_{4}$ is stable only for $\mathrm{P}_{\mathrm{N} 2}>10^{0.017}$ atm or $\mathrm{P}_{\mathrm{N} 2}<10^{0.017}$ atm.

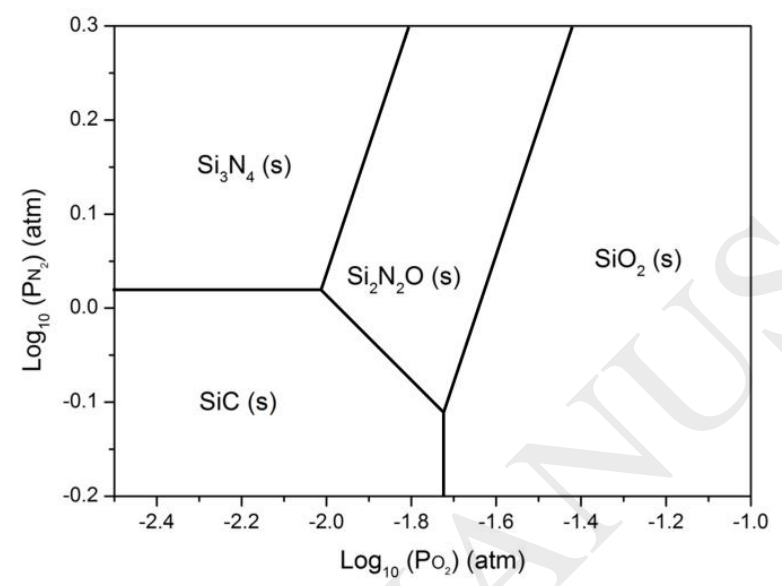

Figure 2: Phase stability diagram of the system Si-C-O-N at $1400{ }^{\circ} \mathrm{C}$ as a function of the partial pressure of $\mathrm{N}_{2}$ and $\mathrm{O}_{2}$.

Figure 3(a) - 3(c) shows XRD patterns obtained from the reference graphite, the $\mathrm{g} / \mathrm{SiC}$, and the $\mathrm{g} / \mathrm{Si}_{3} \mathrm{~N}_{4}$ composite samples. The peaks assigned to graphite (black squares) appear in all samples, having the strongest intensity, suggesting that the graphite matrix is the major phase in these specimens. As indicated in Fig. 3(b), the composite containing SiC particles shows a beta phase $(\beta-\mathrm{SiC})$ which corresponds to the $\mathrm{SiC}$ reinforcement (red circles). In the case of $\mathrm{g} / \mathrm{Si}_{3} \mathrm{~N}_{4}$ composite (Fig. 3(c)), the XRD pattern indicates the formation of a mixture of $\beta-\mathrm{SiC}, \beta-\mathrm{Si}_{3} \mathrm{~N}_{4}$ (blue triangles) and $\alpha-\mathrm{Si}_{3} \mathrm{~N}_{4}$ (green diamonds) in the graphite matrix (black squares). 


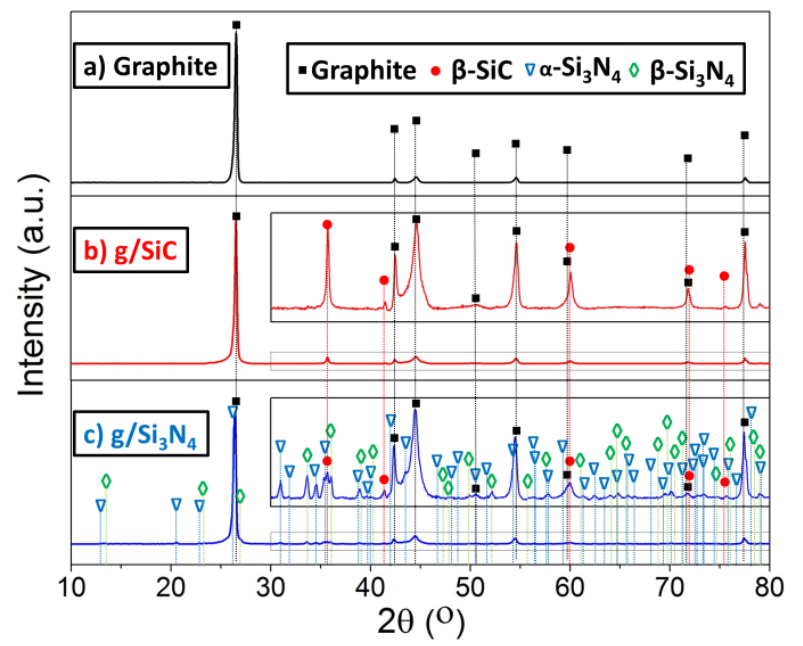

Figure 3: XRD patterns of the (a) graphite, (b) $g / \mathrm{SiC}$, and (c) $\mathrm{g} / \mathrm{Si}_{3} \mathrm{~N}_{4}$ composite specimens. The peak positions of the graphite, the $\beta-\mathrm{SiC}$, the $\alpha-\mathrm{Si}_{3} \mathrm{~N}_{4}$, and the $\beta-\mathrm{Si}_{3} \mathrm{~N}_{4}$ phases are marked with black squares, red circles, blue triangles, and green diamonds, respectively. The inserts in Fig. 3(b) and 3(c) show a magnification of the $2 \theta$ angles between $30^{\circ}$ and $80^{\circ}$ for the better clarity of the peaks.

Table I shows the fraction of phases obtained from the XRD data in wt\%.

Table I. The phase fractions of graphite and composites of graphite infiltrated by Si slurry and heated in $\mathrm{Ar}(\mathrm{g} / \mathrm{SiC})$ and $\mathrm{N}_{2}\left(\mathrm{~g} / \mathrm{Si}_{3} \mathrm{~N}_{4}\right)$ extracted from XRD.

\begin{tabular}{|c|c|c|c|c|}
\hline Sample & $\begin{array}{c}\text { Graphite } \\
(\text { wt.\% })\end{array}$ & $\begin{array}{c}\beta-\mathrm{SiC} \\
(\text { wt. } \%)\end{array}$ & $\begin{array}{c}\alpha-\mathrm{Si}_{3} \mathrm{~N}_{4} \\
(\text { wt.\%) }\end{array}$ & $\begin{array}{c}\beta-\mathrm{Si}_{3} \mathrm{~N}_{4} \\
\text { (wt.\%) }\end{array}$ \\
\hline Graphite & 100 & - & - & - \\
\hline $\mathrm{g} / \mathrm{SiC}$ & 89 & 11 & - & - \\
\hline $\mathrm{g} / \mathrm{Si}_{3} \mathrm{~N}_{4}$ & 79 & 2 & 11 & 8 \\
\hline
\end{tabular}

The bulk density, open porosity, and average Vickers hardness of the original reference graphite block, the graphite infiltrated by $\mathrm{SiC}$ particles $(\mathrm{g} / \mathrm{SiC})$ and the graphite infiltrated by $\mathrm{Si}_{3} \mathrm{~N}_{4}$ particles $\left(\mathrm{g} / \mathrm{Si}_{3} \mathrm{~N}_{4}\right)$ are shown in Table II.

Table II. Bulk density, open porosity, and average Vickers hardness of graphite and composites infiltrated by Si slurry and heated in $\mathrm{Ar}(\mathrm{g} / \mathrm{SiC})$ and $\mathrm{N}_{2}$ atmosphere $\left(\mathrm{g} / \mathrm{Si}_{3} \mathrm{~N}_{4}\right)$.

\begin{tabular}{|c|c|c|c|c|}
\hline Sample & $\begin{array}{c}\text { Bulk Density } \\
\left(\mathrm{g} / \mathrm{cm}^{3}\right)\end{array}$ & $\begin{array}{c}\text { Open Porosity } \\
(\%)\end{array}$ & $\begin{array}{c}\text { Average Vickers } \\
\text { Hardness, } \mathrm{Hv}_{\mathrm{v}}(\mathrm{MPa})\end{array}$ & $\begin{array}{c}\text { Surface Roughness } \\
\mathrm{S}_{\mathrm{a}}(\mu \mathrm{m})\end{array}$ \\
\hline Graphite & $1.60 \pm 0.01$ & $17.5 \pm 0.4$ & $58.6 \pm 8.1$ & $0.42 \pm 0.02$ \\
\hline $\mathrm{g} / \mathrm{SiC}$ & $1.69 \pm 0.01$ & $15.0 \pm 0.6$ & $144.1 \pm 12.8$ & $0.68 \pm 0.03$ \\
\hline $\mathrm{g} / \mathrm{Si}_{3} \mathrm{~N}_{4}$ & $1.70 \pm 0.01$ & $12.0 \pm 0.7$ & $171.6 \pm 17.1$ & $0.67 \pm 0.04$ \\
\hline
\end{tabular}

The $\mathrm{g} / \mathrm{SiC}$ and $\mathrm{g} / \mathrm{Si}_{3} \mathrm{~N}_{4}$ composites show similar bulk density of $1.69 \mathrm{~g} / \mathrm{cm}^{3}$ and 1.7 $\mathrm{g} / \mathrm{cm}^{3}$, respectively, which is slightly increased compared to the bulk density of graphite $(1.60$ $\mathrm{g} / \mathrm{cm}^{3}$ ), as measured using the Archimedes' method [30]. The $\mathrm{g} / \mathrm{Si}_{3} \mathrm{~N}_{4}$ sample shows the 
lowest open porosity of $\sim 12 \%$ after infiltration, whereas the $\mathrm{g} / \mathrm{SiC}$ composite has slightly increased open porosity of $\sim 15 \%$. The $\mathrm{H}_{\mathrm{V}}$ of the reference graphite block is measured at a value of $59 \mathrm{MPa}$. The $\mathrm{H}_{\mathrm{v}}$ values for the $\mathrm{g} / \mathrm{SiC}$ and the $\mathrm{g} / \mathrm{Si}_{3} \mathrm{~N}_{4}$ composites are higher at 144 and $172 \mathrm{MPa}$, respectively. Although the composites are significantly harder than the reference graphite sample, the measured values of $\mathrm{H}_{\mathrm{v}}$ across the surface of the composites show a wide spread, due to the presence of the random distribution of $\mathrm{SiC}$ or $\mathrm{Si}_{3} \mathrm{~N}_{4}$ particles in the graphitic matrix, resulting in large values of standard deviation (Table II). The reference graphite block shows a roughness of $0.42 \mu \mathrm{m}$, while the composites show an increased roughness of 0.68 and $0.67 \mu \mathrm{m}$.

The surface morphology of the reference graphite, as well as, the $\mathrm{g} / \mathrm{SiC}$, and $\mathrm{g} / \mathrm{Si}_{3} \mathrm{~N}_{4}$ composites is shown in the SEM micrographs of Fig. 4(a) - 4(c). The surface of the reference graphite is shown in Fig. 4(a) comprising grains and pores of different shapes and sizes. From Fig. 4(b) and 4(c), it is observed that the surfaces of the $\mathrm{g} / \mathrm{SiC}$ and $\mathrm{g} / \mathrm{Si}_{3} \mathrm{~N}_{4}$ composites include dark and dispersed bright areas. The dark areas correspond to the graphite matrix, while regions with brighter contrast indicate the presence of $\mathrm{SiC}$ (Fig. 4(b)) or $\mathrm{Si}_{3} \mathrm{~N}_{4}$ particles (Fig. 4(c)). The grains of the reinforcements in the $\mathrm{g} / \mathrm{SiC}$ and $\mathrm{g} / \mathrm{Si}_{3} \mathrm{~N}_{4}$ composites have similar size and shape with the pores of the graphite reference sample. This means that most of the pores are filled with the reinforcements, while only pores with a length of less than $30 \mu \mathrm{m}$ remain empty (insert of Fig. 4(b) and 4(c)). Also, a relatively homogeneous distribution of the reinforcements in the pores is observed throughout the volume of the pores (Fig. 4(b) and 4(c)). The composite containing $\mathrm{Si}_{3} \mathrm{~N}_{4}$ reinforcement shows a higher concentration of particles and lower amount of pores than the $\mathrm{g} / \mathrm{SiC}$ composite. Nevertheless, both composites show lower porosity than graphite, as indicated by Fig. 4. The morphology of pores varies from circular to acicular with sizes between $\sim 5 \mu \mathrm{m}$ and $1 \mathrm{~mm}$ for all samples. The total porosity of the samples is $26 \%, 17 \%$, and $12 \%$ for the reference graphite, the $\mathrm{g} / \mathrm{SiC}$ and the $\mathrm{g} / \mathrm{Si}_{3} \mathrm{~N}_{4}$ samples, respectively, as obtained from the SEM micrographs using QDIA calculations.
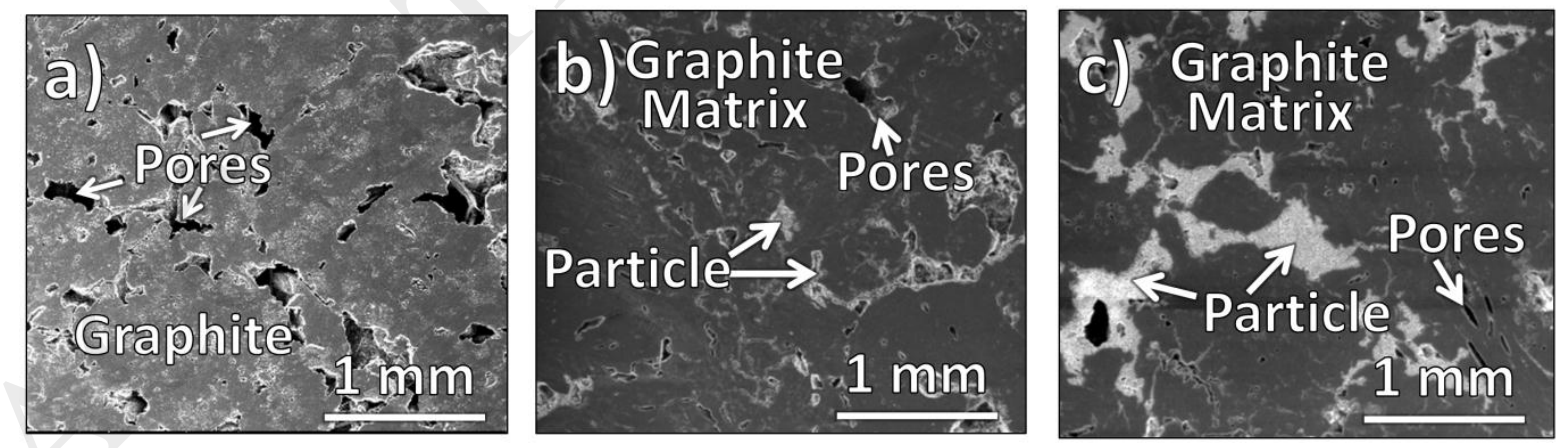

Figure 4: Plan-view SEM micrographs of the (a) reference graphite block, (b) $\mathrm{g} / \mathrm{SiC}$ composite and (c) $\mathrm{g} / \mathrm{Si}_{3} \mathrm{~N}_{4}$ composite.

The morphology of the reinforcement of $\mathrm{g} / \mathrm{SiC}$ and $\mathrm{g} / \mathrm{Si}_{3} \mathrm{~N}_{4}$ composite is assessed from Fig. 5(a) and 5(b), respectively. Figure 5 shows SEM plan views of the reinforcements 
in the $\mathrm{g} / \mathrm{SiC}$ (Fig. 5(a)) and $\mathrm{g} / \mathrm{Si}_{3} \mathrm{~N}_{4}$ (Fig. 5(b)) composites, accompanied by EDX spectra acquired from different areas of the samples, corresponding to fine grains, blade-like and needle-like grains, as well as whiskers. In Fig. 5(a), spectra 1 and 2 correspond to whiskers and small grains of $\mathrm{SiC}$, respectively, while in Fig. 5(b), spectra 1, 2, 3, 4, and 5 correspond to needle-like $\alpha-\mathrm{Si}_{3} \mathrm{~N}_{4}, \alpha-\mathrm{Si}_{3} \mathrm{~N}_{4}$ fine grains, blade-like $\beta-\mathrm{Si}_{3} \mathrm{~N}_{4}, \beta-\mathrm{SiC}$ whiskers, and $\beta-\mathrm{SiC}$ grains, respectively. The plan view SEM micrograph of Fig. 5(a) suggests that the $\mathrm{g} / \mathrm{SiC}$ composite is formed from stacked aggregates of SiC-nuclei (spectrum 2), including a small number of thin whiskers (spectrum 1), distributed around the aggregates. Figure 5(b) reveals that the $\mathrm{g} / \mathrm{Si}_{3} \mathrm{~N}_{4}$ reinforcement presents a mixture of blade-like (spectrum 3) and fine grains (spectrum 2), needle-like structures (spectrum 1) and whiskers (spectrum 4). This type of microstructure has been observed in the past for $\mathrm{SiC}$ and $\mathrm{Si}_{3} \mathrm{~N}_{4}$ produced by mixture of graphite and $\mathrm{Si}$ powders and heating in the coke bed at $1200-1400{ }^{\circ} \mathrm{C}$ and by $\mathrm{SiC}$ and $\mathrm{Si}$ powders heated in a flame-isolation nitrition shuttle kiln at $1200-1450{ }^{\circ} \mathrm{C}$ in nitrogen [28], [27], [34], [35]. The grains with blade morphology appear to be the largest with a diameter of $\sim 10 \mu \mathrm{m}$. The fine grains with a size of less than $0.5 \mu \mathrm{m}$ are located around these blade-like grains (Fig. 5(b)). The needle-like grains and the whiskers appear to be surrounded by the blade-like and fine grains (Fig. 5(b)). In all EDX spectra of Fig. 5, the peak at an energy of 0-0.1 keV corresponds to noise from the detector. The peak intensities differ possibly due to the fact that the spectra were obtained from areas of different porosity affecting it. 

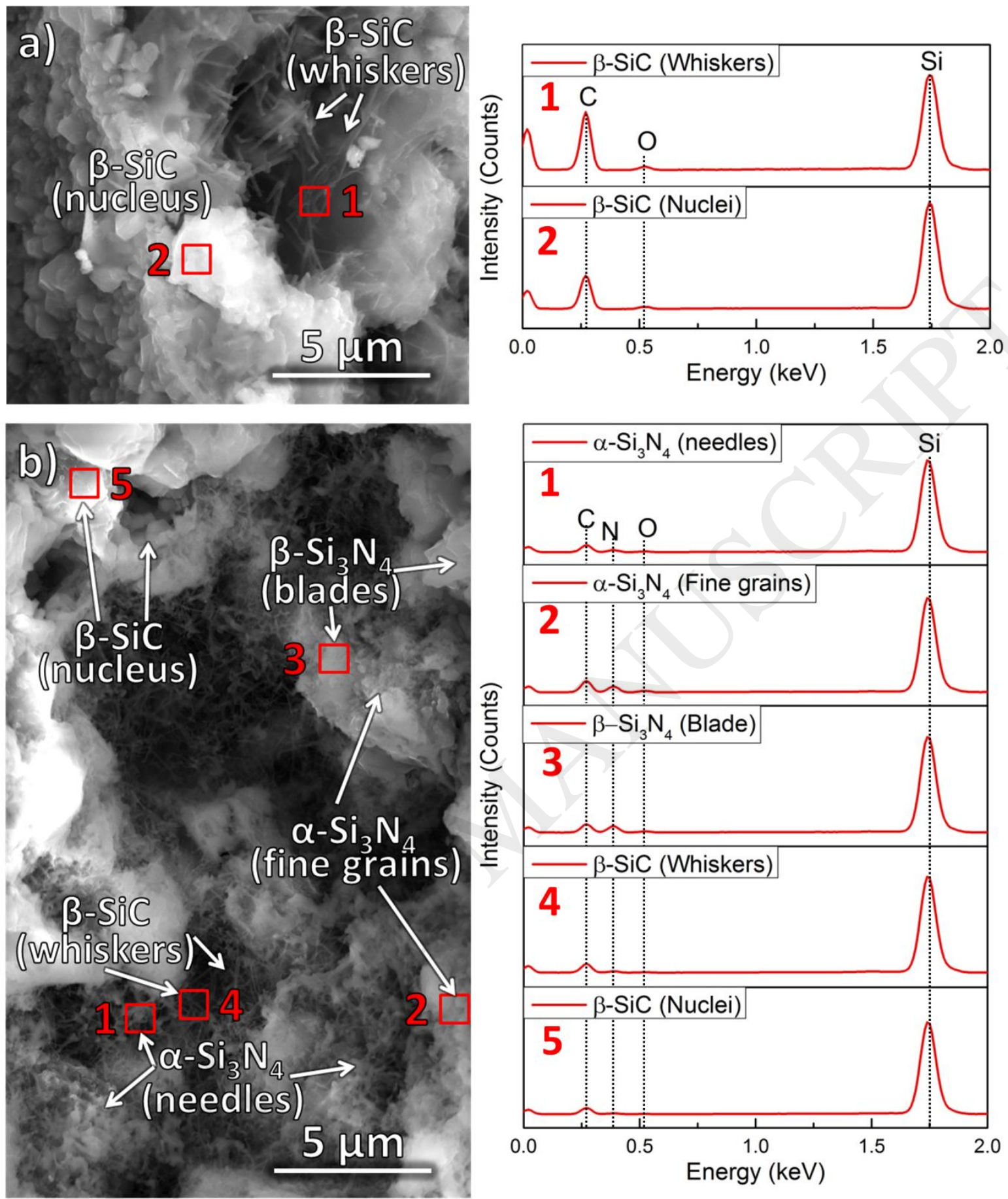

Figure 5: SEM micrographs, acquired in secondary electron mode, accompanied by EDXspectra obtained from within the (a) $\mathrm{g} / \mathrm{SiC}$ and (b) $\mathrm{g} / \mathrm{Si}_{3} \mathrm{~N}_{4}$ reinforcements of the composites. Fine grains, blade-like, needle-like features, and whiskers are observed.

\subsection{Friction and wear}

The CoF of the graphite, $\mathrm{g} / \mathrm{SiC}$, and $\mathrm{g} / \mathrm{Si}_{3} \mathrm{~N}_{4}$ samples, measured using a load of $10 \mathrm{~N}$ at a sliding speed of $0.04 \mathrm{~m} / \mathrm{s}$ with an unlubricated pin-on-disk test, is shown as a function of time for a duration of $3600 \mathrm{~s}$ in Fig. 6(a). The $\mathrm{CoF}$ of the graphite and the composite samples ranges between $\sim 0.15$ and 0.20 , with an average value of 0.17 as is shown in Fig. 6(b). The normalized wear rate $\left(\mathrm{K}_{\mathrm{D}}\right)$ of all samples is calculated using eq. (3) and is shown in Fig. 6(b). 
The $\mathrm{g} / \mathrm{SiC}$ and $\mathrm{g} / \mathrm{Si}_{3} \mathrm{~N}_{4}$ composites exhibit wear rates that are $55 \%\left(77.7 \mu \mathrm{m}^{3} / \mathrm{Nmm}\right)$ and $75 \%$ $\left(42.8 \mathrm{~m}^{3} / \mathrm{Nmm}\right)$ lower than the wear rate of the reference graphite sample (174.0 $\left.\mu \mathrm{m}^{3} / \mathrm{Nmm}\right)$.
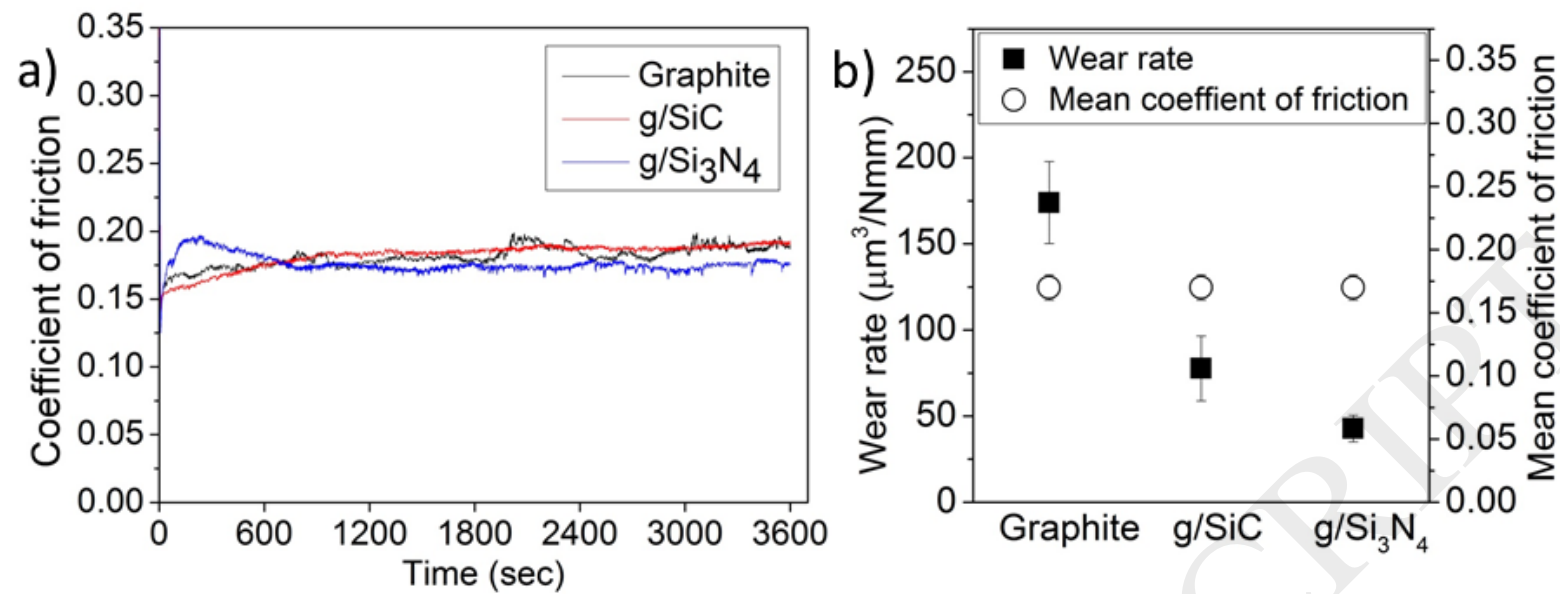

Figure 6: (a) Coefficient of friction (CoF) as a function of time and (b) mean coefficient of friction and normalized wear rate $\left(\mathrm{K}_{\mathrm{D}}\right)$ for the reference graphite block, the $\mathrm{g} / \mathrm{SiC}$, and the $\mathrm{g} / \mathrm{Si}_{3} \mathrm{~N}_{4}$ composite sample, after a pin-on-disk test using a normal load of $10 \mathrm{~N}$ and a sliding speed of $4 \mathrm{~cm} / \mathrm{s}$.

\section{Discussion}

4.1 Synthesis processes, structure, and mechanical properties of the composites.

The synthesis processes of graphite composites containing $\mathrm{SiC}$ or $\mathrm{Si}_{3} \mathrm{~N}_{4}$ reinforcements in Ar or $\mathrm{N}_{2}$ flow, respectively, include the penetration of the Si slurry in the pores of the graphitic block. Here, the formed Si-containing species infiltrate in the pores and are deposited on their surface. Eventually, they coalesce and create solid deposits, filling the voids, as can be seen in the SEM micrographs of Fig. 4. Two main factors assist the successful infiltration and the homogeneous distribution of the reinforcements in the pores of the graphitic blocks: (a) the use of dispersant in the Si slurry instead of the use of powder and (b) the application of a vacuum during the infiltration. The use of ceramic powders for filling the voids of porous materials is a well-known method of reinforcing composites, accompanied however by agglomeration of the powder [36]. Using a dispersant in the slurry instead, yields a homogeneous distribution of the Si powders in the solution. Hence, the agglomeration observed in the case of powders is avoided and it improves the penetration. The application of a vacuum during the infiltration removes the residual air from the pores of the graphite block and thus, the penetration of the slurry into the pores of graphite is facilitated. The successful infiltration is verified by the reduced total porosity of $17 \%$ and $12 \%$ for the $\mathrm{g} / \mathrm{SiC}$ and $\mathrm{g} / \mathrm{Si}_{3} \mathrm{~N}_{4}$ composites, respectively, after processing, as indicated in Table II.

According to the phase diagram of Fig. 2, during the heat treatment at $1400{ }^{\circ} \mathrm{C}$, gaseous phases of $\mathrm{SiO}$ and $\mathrm{CO}$ are formed due to oxidation of $\mathrm{Si}(\mathrm{s})$ and $\mathrm{C}(\mathrm{s})$, respectively, (eq.(4)-(5)) [27]: 


$$
\begin{aligned}
& 2 S i(s)+O_{2}(g) \rightarrow 2 \operatorname{SiO}(g) ; \Delta G_{1}\left(1400^{\circ} \mathrm{C}\right) \sim-479 \mathrm{~kJ} / \mathrm{mol} \\
& 2 C(s)+O_{2}(g) \rightarrow 2 \mathrm{CO}(g) ; \Delta G_{2}\left(1400^{\circ} \mathrm{C}\right) \sim-517 \mathrm{~kJ} / \mathrm{mol}
\end{aligned}
$$

Moreover, $\mathrm{CO}(\mathrm{g})$ facilitates the formation of $\mathrm{Si}(\mathrm{g})$ and $\mathrm{SiO}(\mathrm{g})$ which are produced following the reactions of eq.(6) and eq.(7)) (Fig. 2) [37], [38]:

$$
\begin{aligned}
\operatorname{Si}(s) & \rightarrow \operatorname{Si}(g) \\
\operatorname{Si}(s)+\operatorname{CO}(g) & \rightarrow \operatorname{SiO}(g)+C(s)
\end{aligned}
$$

Here, the $\mathrm{O}_{2}$ is consumed during the formation of $\mathrm{CO}$ and $\mathrm{SiO}$ gases. Also, it is established that the partial pressure of $\mathrm{SiO}$ is higher than of $\mathrm{Si}$ in the $\mathrm{Si}-\mathrm{O}-\mathrm{C}$ and $\mathrm{Si}-\mathrm{O}-\mathrm{C}-\mathrm{N}$ thermodynamic systems (Fig. 2) [27]. The formation of $\mathrm{SiC}$ and $\mathrm{Si}_{3} \mathrm{~N}_{4}$ particles is better illustrated in Fig. 7(a) - 7(d) and Fig. 7(e) - 7(h) and occurs in an atmosphere which contains $\mathrm{SiO}-\mathrm{Si}-\mathrm{CO}$ (Fig. 7(a)) and SiO-Si-CO-N 2 (Fig. 7(e)), respectively.

According to our XRD and SEM results, the $\mathrm{g} / \mathrm{SiC}$ composite contains only one phase, this of $\beta$-SiC (Fig. 3(b)), presenting two allotropic structures; nuclei and whiskers (Fig. 5). This suggests that two different reaction mechanisms are involved for the formation of $\beta$ $\mathrm{SiC}$ inclusion. Fig. 7(a) and 7(b) show the schematic illustration of the gaseous ( $\mathrm{Si}(\mathrm{g})$, $\mathrm{SiO}(\mathrm{g}), \mathrm{CO}(\mathrm{g}))$ and solid phases $(\mathrm{Si}(\mathrm{s})$ and $\mathrm{C}(\mathrm{s}))$ of the substances partaking in the reactions during the formation process of the $\mathrm{g} / \mathrm{SiC}$ composite. The schematic illustration of Fig. 7(a) $7(\mathrm{~d})$, describes the steps for the formations of the $\beta$-SiC nuclei and whiskers. It is safe to assume that $\mathrm{Si}(\mathrm{g})$ and $\mathrm{SiO}(\mathrm{g})$ are diffused in the graphite matrix at a temperature of $1400{ }^{\circ} \mathrm{C}$ and react with $\mathrm{C}$ dangling bonds of the matrix to form $\mathrm{Si}-\mathrm{C}$ and $\mathrm{Si}-\mathrm{O}-\mathrm{C}$ bonds (Fig. 7(b)), according to the reaction of eq. (8) [39]:

$$
\operatorname{Si}(s)+\operatorname{SiO}(g)+3 C(s) \rightarrow 2 \operatorname{SiC}(s)+\operatorname{CO}(g) ; \Delta G_{2}\left(1400^{\circ} C\right) \sim-140 \mathrm{~kJ} / \mathrm{mol}
$$

The direct formation of $\mathrm{SiC}$ according to the reaction of eq. (9) [39]:

$$
\operatorname{Si}(s)+C(s) \rightarrow \operatorname{SiC}(s) ; \Delta G_{3}\left(1400^{\circ} \mathrm{C}\right) \sim-60 \mathrm{~kJ} / \mathrm{mol}
$$

cannot be entirely excluded, despite the fact that the $\Delta G$ of the reaction of eq. (8) is $\sim 45 \%$ lower than the $\Delta G$ of the reaction of (eq. 9). However, this implies that the reaction described by eq. (8) is the dominant mechanism for the formation of the $\beta$-SiC nuclei in our composite. 

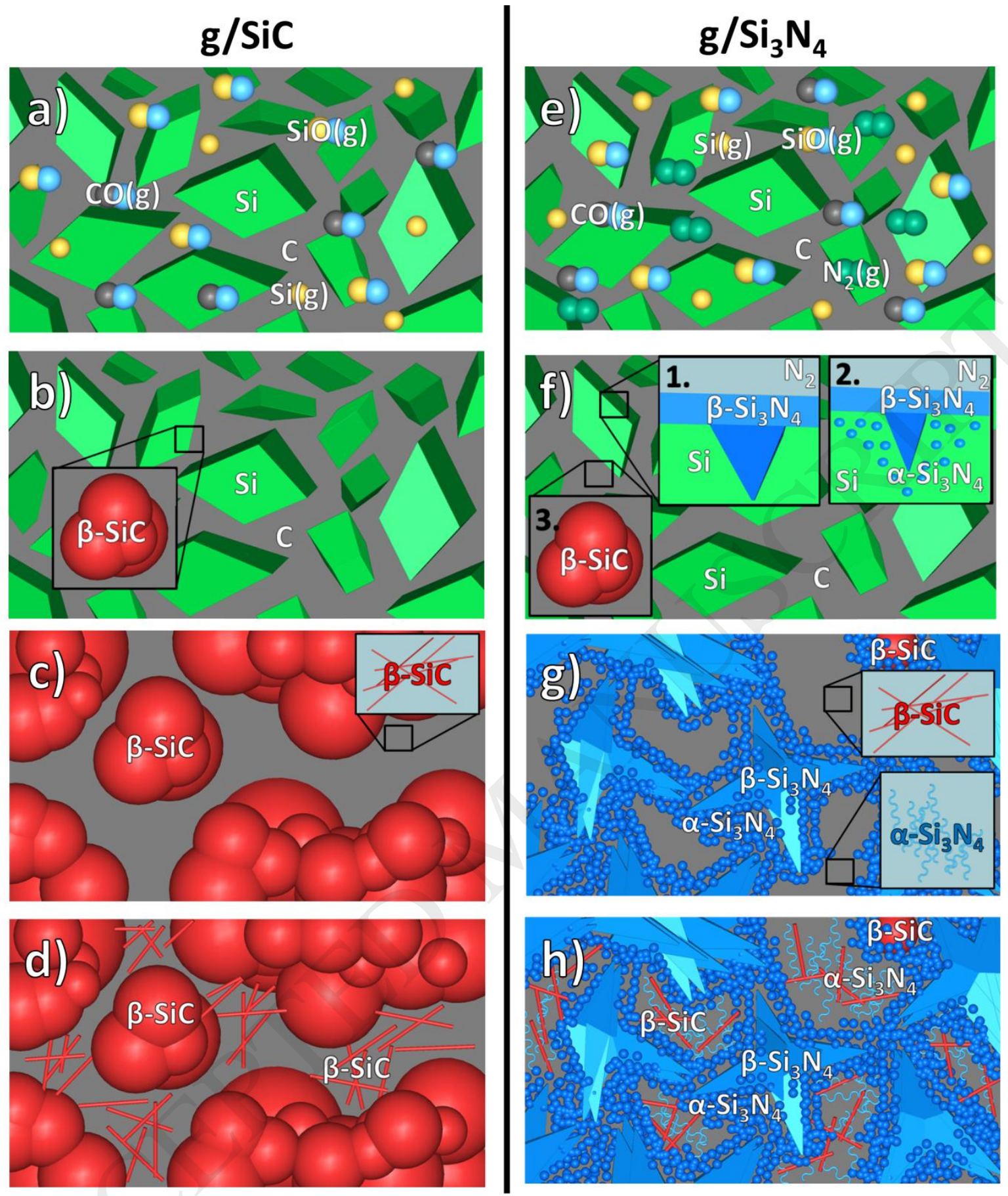

Figure 7: (a) Schematic illustration of the microstructures of $\mathrm{Si}(\mathrm{s})$ and $\mathrm{C}(\mathrm{s})$ in a gaseous atmosphere of $\mathrm{Si}(\mathrm{g}), \mathrm{SiO}(\mathrm{g})$ and $\mathrm{CO}(\mathrm{g})$ formed by $\mathrm{Si}$ vaporization and, $\mathrm{Si}$ and $\mathrm{C}$ oxidation. (b) Formation of $\beta$-SiC nuclei and(c) $\beta$-SiC whiskers during the reactions described by eq.(4) - eq.(9).(d) The $\beta$-SiC particles embedded in the $\mathrm{g} / \mathrm{SiC}$ composite. (e) Schematic illustration of the microstructures of $\mathrm{Si}(\mathrm{s})$ and $\mathrm{C}(\mathrm{s})$ in a gaseous atmosphere of $\mathrm{Si}(\mathrm{g}), \mathrm{SiO}(\mathrm{g}), \mathrm{CO}(\mathrm{g})$ and $\mathrm{N}_{2}$ (g) formed by $\mathrm{Si}$ vaporization and, $\mathrm{Si}$ and $\mathrm{C}$ oxidation. (f) Formation of blade-like grains of $\beta-\mathrm{Si}_{3} \mathrm{~N}_{4}$, fine grains of $\alpha-\mathrm{Si}_{3} \mathrm{~N}_{4}$, and aggregates of $\beta-\mathrm{SiC}$ in the $\mathrm{g} / \mathrm{Si}_{3} \mathrm{~N}_{4}$ composite. $(\mathrm{g})$ Formation of $\alpha-\mathrm{Si}_{3} \mathrm{~N}_{4}$ needle-like grains and $\beta-\mathrm{SiC}$ whisker in the $\mathrm{g} / \mathrm{Si}_{3} \mathrm{~N}_{4}$ composite, and (h) the different $\alpha-\mathrm{Si}_{3} \mathrm{~N}_{4}, \beta-\mathrm{Si}_{3} \mathrm{~N}_{4}, \beta-\mathrm{SiC}$ particles embedded in the $\mathrm{g} / \mathrm{Si}_{3} \mathrm{~N}_{4}$ composite. 
The $\beta$-SiC whiskers are formed according to the following reactions, as described by Li et al. in ref. [27] (eq. (10) and eq. (11)) (Fig. 7(c)) [40], [41]:

$$
\begin{gathered}
2 \mathrm{Si}(g)+2 \mathrm{CO}(g) \rightarrow 2 \mathrm{SiC}(s)+\mathrm{O}_{2}(g) \\
\operatorname{SiO}(g)+3 \mathrm{CO}(g) \rightarrow \operatorname{SiC}(s)+2 \mathrm{CO}_{2}(g)
\end{gathered}
$$

During the heat treatment at a temperature of $1400{ }^{\circ} \mathrm{C}$, the carbon atoms of graphite are thermally oxidized forming broken $\mathrm{C}$ bonds, which favor the production of both $\mathrm{SiC}$ nuclei and whiskers (Fig. 7(c) and 7(d)) [27]. Thus, the reinforcement in the $\mathrm{g} / \mathrm{SiC}$ is formed by $\beta$ $\mathrm{SiC}$ with the form of nuclei-like grains surrounded by whiskers structure (Fig. 7(d)).

In the case of $\mathrm{g} / \mathrm{Si}_{3} \mathrm{~N}_{4}$ composite, the presence of three different phases, i.e., $\alpha-\mathrm{Si}_{3} \mathrm{~N}_{4}$, $\beta-\mathrm{Si}_{3} \mathrm{~N}_{4}$, and $\beta-\mathrm{SiC}$, as well as, the variety of features that are observed in the morphology (Fig. 5(b) and Fig. 7(e) - 7(h)), suggest that several reactions occur during the infiltration process. Fig. 7(e) and 7(f) show the schematic illustration of the gaseous $(\mathrm{Si}(\mathrm{g}), \mathrm{SiO}(\mathrm{g})$, $\mathrm{CO}(\mathrm{g})$, and $\mathrm{N}_{2}(\mathrm{~g})$ ) and solid phases ( $\mathrm{Si}(\mathrm{s})$ and $\mathrm{C}(\mathrm{s})$ ) of the substances partaking in the reactions during the formation process of the $\mathrm{g} / \mathrm{Si}_{3} \mathrm{~N}_{4}$ composite. The formation of $\mathrm{g} / \mathrm{Si}_{3} \mathrm{~N}_{4}$ composite follows three steps. In the first step, $\mathrm{N}_{2}(\mathrm{~g})$ reacts directly with $\mathrm{Si}(\mathrm{s})$ to form $\beta$ $\mathrm{Si}_{3} \mathrm{~N}_{4}$ with blade-like morphology according to the following reaction (eq. (12)) (Fig. 7(f-1)) [28]:

$$
3 S i(s)+2 N_{2}(g) \rightarrow S i_{3} N_{4}(s) ; \Delta G_{4}\left(1400^{\circ} \mathrm{C}\right) \sim-195 \mathrm{~kJ} / \mathrm{mol}
$$

In the second step, following the reaction of eq. (12) the formation of $\alpha-\mathrm{Si}_{3} \mathrm{~N}_{4}$ with fine grain morphology originates from the reaction between $\mathrm{Si}(\mathrm{g})$ and $\mathrm{N}_{2}(\mathrm{~g})$ [42] (insert 2 in Fig. 7 (f)). Here, nitride nuclei are formed, while $\mathrm{Si}(\mathrm{g})$ diffuses on the nuclei surface and condensates, leaving a zone occupied by a low $\mathrm{N}_{2}(\mathrm{~g})$ content. Consequently, the pores around the $\beta-\mathrm{Si}_{3} \mathrm{~N}_{4}$ grains are filled with $\mathrm{N}_{2}$, which reacts with $\mathrm{Si}(\mathrm{g})$ or $\mathrm{SiO}(\mathrm{g})$, forming $\alpha-\mathrm{Si}_{3} \mathrm{~N}_{4}$ [42], [43], [29]. The formation of $\beta$-SiC aggregates (Fig. 7(f)), as observed in the g/SiC composite following the reaction described in eq. (8) cannot be excluded. However, the XRD results display very low intensity of the peaks corresponding to $\beta$-SiC, suggesting that the amount of $\mathrm{SiC}$ in the $\mathrm{g} / \mathrm{Si}_{3} \mathrm{~N}_{4}$ composite is low (Fig. 3(c)), due to the fact that the $\Delta \mathrm{G}$ associated with the $\beta-\mathrm{Si}_{3} \mathrm{~N}_{4}$ (cf. eq. (12)) is $\sim 55 \mathrm{~kJ} / \mathrm{mol}$ lower than the $\Delta \mathrm{G}$ of $\beta$-SiC (cf. eq. (8)). Moreover, the simultaneous formation of $\beta-\mathrm{SiC}$ with a morphology of fine grains, similar to the morphology of fine grains of $\alpha-\mathrm{Si}_{3} \mathrm{~N}_{4}$, is not excluded either and thus, the $\beta$-SiC aggregates cannot be resolved with certainty.

The third step includes the formation of few whiskers containing $\beta$-SiC, following the reactions described in eq. (10) and eq. (11). The low concentration of $\mathrm{SiC}$ whiskers observed in the pores of the $\mathrm{g} / \mathrm{Si}_{3} \mathrm{~N}_{4}$ (cf. Fig. 5(b)) suggests that these reactions are completed by consuming a relatively small amount of residual $\mathrm{Si}, \mathrm{SiO}$, and $\mathrm{CO}$ gases. The formation of $\alpha-$ $\mathrm{Si}_{3} \mathrm{~N}_{4}$ with a needle-like morphology follows the reactions of eq. (13) and eq. (14) (Fig 7(g)) [43], [28],

$$
3 \mathrm{SiO}(g)+2 N_{2}(g) \rightarrow \mathrm{Si}_{3} N_{4}(s)+\frac{3}{2} \mathrm{O}_{2}(g)
$$




$$
3 \mathrm{SiO}(g)+3 C(s)+2 N_{2}(g) \rightarrow \mathrm{Si}_{3} N_{4}(s)+3 \mathrm{CO}(g)
$$

Thus, the blade-like grains of $\beta-\mathrm{Si}_{3} \mathrm{~N}_{4}$ particles are surrounded by fine grains of $\alpha-\mathrm{Si}_{3} \mathrm{~N}_{4}$ and aggregates of $\beta-\mathrm{SiC}$; and these are surrounded by $\alpha-\mathrm{Si}_{3} \mathrm{~N}_{4}$ needle-like grains and $\beta$-SiC whiskers (Fig. 7(h)) forming an onion-like structure (Fig. 7(h)).

The significant increase of the hardness of the composites compared to the reference graphite sample can be attributed to the increased density and decreased porosity of the composites after the infiltration (Table II) [44]. This is a result of the deposition of hard SiC and $\mathrm{Si}_{3} \mathrm{~N}_{4}$ particles in the pores of the soft graphitic matrix, contributing to the measured hardness values, which is confirmed by the relatively high errors of the measurements. Here, the $\mathrm{Si}_{3} \mathrm{~N}_{4}$ particles contribute to the increase of the toughness of graphite to a higher degree than the $\mathrm{SiC}$ particles due to the higher hardness of $10 \mathrm{GPa}$ of the $\mathrm{Si}_{3} \mathrm{~N}_{4}$ compared to the hardness of $7 \mathrm{GPa}$ of the SiC [45], [46]. Moreover, it can be inferred that both increased density and decreased porosity contribute to the improvement of the mechanical properties of the graphite sample when the reinforcements are added in the pores. However, the density of $\mathrm{g} / \mathrm{SiC}$ and $\mathrm{g} / \mathrm{Si}_{3} \mathrm{~N}_{4}$ composites is similar with values of 1.69 and $1.70 \mathrm{~g} / \mathrm{cm}^{3}$ (Table II) and the difference between these composites can be associated to the lower porosity of $\mathrm{g} / \mathrm{Si}_{3} \mathrm{~N}_{4}(12 \%)$ against the porosity of $\mathrm{g} / \mathrm{SiC}$ composite (15\%) (cf. Table II).

\subsection{Wear and friction of composites.}

The wear rate of the samples shows a dependency on the hardness of the samples (cf. Fig. 6(b) and Table I), which agrees with Archard's law of wear [44], [47]. The harder $\mathrm{g} / \mathrm{Si}_{3} \mathrm{~N}_{4}$ composite is the more wear resilient among all tested samples and the reference graphite sample exhibits the highest wear rate and also the lowest hardness (cf. Fig. 6(b) and Table II). This dependency of the wear rate on the hardness of composite materials has been investigated also by Lim et al. and our composites follow a similar trend [34].

A notable observation is that the reference graphite sample and the two reinforced composite samples exhibit very similar coefficient of friction. This implies that the friction mechanism is governed by the main body of the composite, which is the soft graphite matrix in all samples. This is an important observation since the reinforcements achieve much higher wear resistance by the introduction of harder particles in their structure, yet retaining the friction coefficient value at the same level as graphite, which is considered as solid lubricant (Fig. 6(a)). In all cases, the nature and origin of the wear debris do not seem to influence the friction mechanism. Here, the most possible scenario is that the higher volume of the wear debris was generated and pushed at the sides of the wear tracks during run-in, contributing least to the friction mechanisms. The amount of the remaining debris in the wear tracks though is not adequate to affect the values of friction coefficient. Thus, we assume that the values of the coefficient of friction are controlled by the graphitic nature of the surface and by possible passivation of the surface with $\mathrm{H}$. Here, $\mathrm{C}$ dangling bonds are created after the first pass of the pin from the surface, which bond to $\mathrm{H}$ before the next cycles $(\sim 50 \%$ humidity during tests) [48]. This hydrogenated graphitic surface contributes greatly to the modulation of the values of friction [49]. This is supported by the very similar friction values of all tested samples (Fig. 6(a)). 
The pronounced fluctuations in the values of friction coefficient (Fig. 6(a)) can be related to the continuous production and loss of wear debris at the contact. During the production of wear debris, the CoF increases and during the debris loss, the CoF decreases again. This operation is verified by the cyclic trend observed in $\mathrm{CoF}$, where the fluctuations in the values occur every 250-300 s (Fig. 6(a)). This trend is due to the soft and lubricious nature of the graphite matrix, which allows for effortless creation of the soft debris [50].

\section{Conclusion}

$\mathrm{SiC}$ or $\mathrm{Si}_{3} \mathrm{~N}_{4}$ particles were incorporated in porous graphite blocks using a $\mathrm{Si}$ slurry infiltration method and carbonization or nitration at $1400{ }^{\circ} \mathrm{C}$ for $2 \mathrm{~h}$, respectively. $\mathrm{SiC}$ and $\mathrm{Si}_{3} \mathrm{~N}_{4}$ reinforcing graphite composites show wear rate of $55 \%$ and $75 \%$, respectively, significantly lower than the wear rate of graphite. Here, the hardness increase of $146 \%$ in the SiC-reinforced graphite composite and $193 \%$ in the $\mathrm{Si}_{3} \mathrm{~N}_{4}$-reinforced graphite composite, contributes significantly to the enhancement of the wear performance. The decreased porosity (14-31\% lower porosity than graphite) and increased density (6\% higher density than graphite) also contribute to wear reduction, but to a lesser extent. Furthermore, the $\mathrm{Si}_{3} \mathrm{~N}_{4}$ reinforcements show the best performance, offering the highest wear resistance in the study (wear rate of $42.8 \mu \mathrm{m}^{3} / \mathrm{Nmm}$ ), without impairing the lubricious properties of graphite.

As a result, the enhanced tribological operation of the composites is due to two different factors:

(a) The wear resistance of the composites is governed by the hard $\mathrm{SiC}$ and $\mathrm{Si}_{3} \mathrm{~N}_{4}$ particles in the morphology of bulk graphite and in this case no contributions from the soft matrix are involved.

(b) The graphite matrix of the composites contributes mostly to the lubrication of the contacts during testing and to the friction evolution with debris creation and circulation in the contact, resulting in the highly desirable low values of the coefficient of friction (0.17).

Hence, our method of infiltration, which incorporates $\mathrm{SiC}$ and $\mathrm{Si}_{3} \mathrm{~N}_{4}$ particles in the porosity of bulk graphite is proven very effective for increasing its wear resistance through alterations in its morphology, leading to longer lifetimes. These properties are very useful for applications, such as sealing rings, bearings, and piston rings which can use protected graphitic-based films and coatings, or components, such as electrodes, extrusion guides, crucibles, and molds.

\section{Acknowledgements}

M.H. acknowledges financial support from Bawtry Carbon International Limited and EPSRC (EP/L01680X/1) through the Materials for Demanding Environments Centre for Doctoral Training. P.X. and K.D.B. acknowledges financial support from the Department of Business, Energy and Industrial Strategy (BEIS) of the UK Government. 


\section{References}

[1] H.O. Pierson, Handbook of Carbon, Graphite, Diamonds and Fullerenes: Processing, Properties and Applications, Elsevier Science, 2012. https://books.google.co.uk/books?id=Ub-GAAAAQBAJ.

[2] F.J. Clauss, Solid Lubricants and Self-Lubricating Solids, Elsevier Science, 2012. https://books.google.co.uk/books?id=5mYSKeb7c68C.

[3] M. Kanari, K. Tanaka, S. Baba, M. Eto, Nanoindentation behavior of a twodimensional carbon-carbon composite for nuclear applications, Carbon N. Y. 35 (1997) 1429-1437. doi:https://doi.org/10.1016/S0008-6223(97)00042-0.

[4] P.J. Bryant, P.L. Gutshall, L.H. Taylor, A study of mechanisms of graphite friction and wear, Wear. 7 (1964) 118-126. doi:https://doi.org/10.1016/0043-1648(64)90083-3.

[5] H.S. Kim, On the rule of mixtures for the hardness of particle reinforced composites, Mater. Sci. Eng. A. 289 (2000) 30-33. doi:https://doi.org/10.1016/S09215093(00)00909-6.

[6] G.Y. Lee, C.K.H. Dharan, R.O. Ritchie, A physically-based abrasive wear model for composite materials, Wear. 252 (2002) 322-331. doi:https://doi.org/10.1016/S00431648(01)00896-1.

[7] A. Amanov, Y.-S. Pyun, Friction Reduction and Wear Resistance Enhancement of SiC and Si3N4 Ceramics under Dry Conditions, Tribol. Trans. 59 (2016) 491-501. doi:10.1080/10402004.2015.1087081.

[8] H.O. Pierson, Handbook of Refractory Carbides \& Nitrides: Properties, Characteristics, Processing and Apps., Elsevier Science, 1996. https://books.google.co.uk/books?id=K_K7q3jaqXEC.

[9] W. Krenkel, F. Berndt, C/C-SiC composites for space applications and advanced friction systems, Mater. Sci. Eng. A. 412 (2005) 177-181. doi:https://doi.org/10.1016/j.msea.2005.08.204.

[10] Y. Xu, L. Zhang, L. Cheng, D. Yan, Microstructure and mechanical properties of three-dimensional carbon/silicon carbide composites fabricated by chemical vapor infiltration, Carbon N. Y. 36 (1998) 1051-1056. doi:https://doi.org/10.1016/S00086223(98)00076-1.

[11] A. Favre, H. Fuzellier, J. Suptil, An original way to investigate the siliconizing of carbon materials, Ceram. Int. 29 (2003) 235-243. doi:https://doi.org/10.1016/S02728842(02)00110-4.

[12] Y.N. Liang, Z.Y. Ma, S.Z. Li, S. Li, J. Bi, Effect of particle size on wear behaviour of $\mathrm{SiC}$ particulate-reinforced aluminum alloy composites, J. Mater. Sci. Lett. 14 (1995) 114-116. doi:10.1007/BF00456563.

[13] E. Hong, B. Kaplin, T. You, M. Suh, Y.-S. Kim, H. Choe, Tribological properties of copper alloy-based composites reinforced with tungsten carbide particles, Wear. 270 (2011) 591-597. doi:https://doi.org/10.1016/j.wear.2011.01.015. 
[14] J.M. Durand, M. Vardavoulias, M. Jeandin, Role of reinforcing ceramic particles in the wear behaviour of polymer-based model composites, Wear. 181-183 (1995) 833-839. doi:https://doi.org/10.1016/0043-1648(95)90203-1.

[15] H. He, R. Fu, Y. Han, Y. Shen, D. Wang, High Thermal Conductive Si3N4 Particle Filled Epoxy Composites With a Novel Structure, J. Electron. Packag. 129 (2007) 469-472. http://dx.doi.org/10.1115/1.2804097.

[16] H. Arik, Effect of mechanical alloying process on mechanical properties of $\alpha-\mathrm{Si} 3 \mathrm{~N} 4$ reinforced aluminum-based composite materials, Mater. Des. 29 (2008) 1856-1861. doi:https://doi.org/10.1016/j.matdes.2008.03.010.

[17] Y. Zhu, Z. Huang, S. Dong, M. Yuan, D. Jiang, Manufacturing 2D carbon-fiberreinforced $\mathrm{SiC}$ matrix composites by slurry infiltration and PIP process, Ceram. Int. 34 (2008) 1201-1205. doi:https://doi.org/10.1016/j.ceramint.2007.02.014.

[18] Y. Xu, L. Zhang, Three-Dimensional Carbon/Silicon Carbide Composites Prepared by Chemical Vapor Infiltration, J. Am. Ceram. Soc. 80 (1997) 1897-1900. doi:10.1111/j.1151-2916.1997.tb03069.x.

[19] Y. Wang, X. Zhu, L. Zhang, L. Cheng, Reaction kinetics and ablation properties of $\mathrm{C} / \mathrm{C}-\mathrm{ZrC}$ composites fabricated by reactive melt infiltration, Ceram. Int. 37 (2011) 1277-1283. doi:https://doi.org/10.1016/j.ceramint.2010.12.002.

[20] C.B. Lim, T. Yano, T. Iseki, Microstructure and mechanical properties of RBSiC/MoSi2 composite, J. Mater. Sci. 24 (1989) 4144-4151. doi:10.1007/BF01168987.

[21] H.-T. Fang, Z.-D. Yin, J.-C. Zhu, J.-H. Jeon, Y.-D. Hahn, Effect of Al additive in Si slurry coating on liquid Si infiltration into carbon-carbon composites, Carbon N. Y. 39 (2001) 2035-2041. doi:https://doi.org/10.1016/S0008-6223(01)00016-1.

[22] J.-M. Qian, J.-P. Wang, G.-J. Qiao, Z.-H. Jin, Preparation of porous SiC ceramic with a woodlike microstructure by sol-gel and carbothermal reduction processing, J. Eur. Ceram. Soc. 24 (2004) 3251-3259. doi:https://doi.org/10.1016/j.jeurceramsoc.2003.10.042.

[23] C. Yan, R. Liu, Y. Cao, C. Zhang, D. Zhang, Ablation behavior and mechanism of $\mathrm{C} / \mathrm{ZrC}, \mathrm{C} / \mathrm{ZrC}-\mathrm{SiC}$ and $\mathrm{C} / \mathrm{SiC}$ composites fabricated by polymer infiltration and pyrolysis process, Corros. Sci. 86 (2014) 131-141. doi:https://doi.org/10.1016/j.corsci.2014.05.005.

[24] M. Rosso, Ceramic and metal matrix composites: Routes and properties, J. Mater. Process. Technol. 175 (2006) 364-375. doi:https://doi.org/10.1016/j.jmatprotec.2005.04.038.

[25] H.T. Fang, Z. Da Yin, J.C. Zhu, J.H. Jeon, Y.D. Hahn, Effect of Al additive in Si slurry coating on liquid Si infiltration into carbon-carbon composites, Carbon N. Y. 39 (2001) 2035-2041. doi:10.1016/S0008-6223(01)00016-1.

[26] K. Nakano, A. Kamiya, Y. Nishino, T. Imura, T. Chou, Fabrication and Characterization of Three- Dimensional Carbon Fiber Reinforced Silicon Carbide and Silicon Nitride Composites, J. Am. Ceram. Soc. 78 (1995) 2811-2814. doi:10.1111/j.1151-2916.1995.tb08058.x. 
[27] Y. Li, Q. Wang, H. Fan, S. Sang, Y. Li, L. Zhao, Synthesis of silicon carbide whiskers using reactive graphite as template, Ceram. Int. 40 (2014) 1481-1488. doi:https://doi.org/10.1016/j.ceramint.2013.07.032.

[28] M. Long, Y. Li, H. Qin, W. Xue, J. Chen, J. Sun, R. Vasant Kumar, Formation mechanism of Si3N4 in reaction-bonded Si3N4-SiC composites, Ceram. Int. 42 (2016) 16448-16452. doi:10.1016/j.ceramint.2016.05.118.

[29] H.M. Jennings, M.H. Richman, Structure, formation mechanisms and kinetics of reaction-bonded silicon nitride, J. Mater. Sci. 11 (1976) 2087-2098. doi:10.1007/BF02403359.

[30] Standard Test Methods for Apparent Porosity, Water Absorption, Apparent Specific Gravity, and Bulk Density of Burned Refractory Brick and Shapes by Boiling Water BT - Standard Test Methods for Apparent Porosity, Water Absorption, Apparent Specific, (n.d.).

[31] H. WADA, M. WANG, T. TIEN, Stability of Phases in the Si- C- N- O System, J. Am. Ceram. Soc. 71 (1988) 837-840. doi:10.1111/j.1151-2916.1988.tb07532.x.

[32] I.L. Denry, J.A. Holloway, Elastic constants, Vickers hardness, and fracture toughness of fluorrichterite-based glass-ceramics, Dent. Mater. 20 (2004) 213-219. doi:https://doi.org/10.1016/S0109-5641(03)00094-0.

[33] M. Chlipala, J. Schneider, V. Schulze, Experimental Analysis of Microstructured Steel Surfaces for Wet Tribological Applications in the Low Velocity Regime, in: Hindawi Limited, Cairo, 2015.

https://manchester.idm.oclc.org/login?url=https://search.proquest.com/docview/17021 40287 ? accountid $=12253$.

[34] C.Y.H. Lim, D.K. Leo, J.J.S. Ang, M. Gupta, Wear of magnesium composites reinforced with nano-sized alumina particulates, Wear. 259 (2005) 620-625. doi:https://doi.org/10.1016/j.wear.2005.02.006.

[35] J. Chen, N. Li, Y. Wei, B. Han, W. Yan, Influence of carbon sources on nitriding process, microstructures and mechanical properties of Si3N4 bonded $\mathrm{SiC}$ refractories, J. Eur. Ceram. Soc. 37 (2017) 1821-1829. doi:https://doi.org/10.1016/j.jeurceramsoc.2016.12.005.

[36] L. Wang, W. Sigmund, F. Aldinger, A novel class of dispersants for colloidal processing of Si3N4 in non-aqueous media, Mater. Lett. 40 (1999) 14-17. doi:https://doi.org/10.1016/S0167-577X(99)00041-5.

[37] M. Luo, Y. Li, S. Jin, S. Sang, L. Zhao, Microstructural Evolution and Oxidation Resistance of Multi-walled Carbon Nanotubes in the Presence of Silicon Powder at High Temperatures, J. Mater. Sci. Technol. 28 (2012) 599-605. doi:https://doi.org/10.1016/S1005-0302(12)60104-2.

[38] E.A. Gulbransen, S.A. Jansson, The high-temperature oxidation, reduction, and volatilization reactions of silicon and silicon carbide, Oxid. Met. 4 (1972) 181-201. doi:10.1007/BF00613092.

[39] S. Larpkiattaworn, P. Ngernchuklin, W. Khongwong, N. Pankurddee, S. Wada, The 
influence of reaction parameters on the free $\mathrm{Si}$ and $\mathrm{C}$ contents in the synthesis of nanosized SiC, Ceram. Int. 32 (2006) 899-904.

doi:https://doi.org/10.1016/j.ceramint.2005.06.011.

[40] M. Saito, S. Nagashima, A. Kato, Crystal growth of $\mathrm{SiC}$ whisker from the $\mathrm{SiO}$ (g)-CO system, J. Mater. Sci. Lett. 11 (1992) 373-376.

[41] Y.H. Gao, Y. Bando, K. Kurashima, T. Sato, SiC nanorods prepared from $\mathrm{SiO}$ and activated carbon, J. Mater. Sci. 37 (2002) 2023-2029. doi:10.1023/A:1015207416903.

[42] H.M. Jennings, On reactions between silicon and nitrogen, J. Mater. Sci. 18 (1983) 951-967. doi:10.1007/BF00551961.

[43] G. Ziegler, J. Heinrich, G. Wötting, Relationships between processing, microstructure and properties of dense and reaction-bonded silicon nitride, J. Mater. Sci. 22 (1987) 3041-3086. doi:10.1007/BF01161167.

[44] K.D. Bakoglidis, S. Schmidt, M. Garbrecht, I.G. Ivanov, J. Jensen, G. Greczynski, L. Hultman, Low-temperature growth of low friction wear-resistant amorphous carbon nitride thin films by mid-frequency, high power impulse, and direct current magnetron sputtering, J. Vac. Sci. Technol. A Vacuum, Surfaces, Film. 33 (2015) 05E112. doi:10.1116/1.4923275.

[45] Y.V. Milman, S.I. Chugunova, I. V Goncharova, T. Chudoba, W. Lojkowski, W. Gooch, Temperature dependence of hardness in silicon-carbide ceramics with different porosity, Int. J. Refract. Met. Hard Mater. 17 (1999) 361-368. doi:https://doi.org/10.1016/S0263-4368(99)00022-0.

[46] A.K. Mukhopadhyay, S.K. Datta, D. Chakraborty, Hardness of silicon nitride and sialon, Ceram. Int. 17 (1991) 121-127. doi:https://doi.org/10.1016/02728842(91)90040-7.

[47] K. Holmberg, A. Matthews, H. Ronkainen, Coatings tribology—contact mechanisms and surface design, Tribol. Int. 31 (1998) 107-120. doi:https://doi.org/10.1016/S0301679X(98)00013-9.

[48] J. Fontaine, C. Donnet, A. Grill, T. LeMogne, Tribochemistry between hydrogen and diamond-like carbon films, Surf. Coatings Technol. 146-147 (2001) 286-291. doi:https://doi.org/10.1016/S0257-8972(01)01398-6.

[49] S.K. Field, M. Jarratt, D.G. Teer, Tribological properties of graphite-like and diamondlike carbon coatings, Tribol. Int. 37 (2004) 949-956. doi:https://doi.org/10.1016/j.triboint.2004.07.012.

[50] Y. Zhan, G. Zhang, The role of graphite particles in the high-temperature wear of copper hybrid composites against steel, Mater. Des. 27 (2006) 79-84. doi:https://doi.org/10.1016/j.matdes.2004.08.019. 